\title{
A QUALITATIVE STUDY ON THE WORK PERFORMANCE OF NUTRITION TECHNICIANS IN NUTRITION CONTROL IN MEDAN, NORTH SUMATERA
}

\author{
Gayatri Tungga Dewi, Juanita, Zulhaida \\ Masters Program in Public Health, Universitas Sumatera Utara
}

\begin{abstract}
Background: Malnutrition continues to be a major public health problem throughout the developing world, particularly in southern Asia and sub-Saharan Africa. Malnutrition is the most important risk factor for the burden of disease in developing countries. It is the direct cause of about 300,000 deaths per year and is indirectly responsible for about half of all deaths in young children. Nutrition technicians play a key role in providing quality, cost-effective client care, and foodservice management. Nutrition technicians work to plan menus and prepare food for people with special nutritional needs. This study aimed to assess the work performance of nutrition technicians in nutrition control in Medan, North Sumatera.

Subjects and Method: This was a qualitative study conducted in Medan, North Sumatera. A sample of nutrition technicians, health center doctors, municipality health office administrators, and mothers who had malnourished children, was selected for this study. The theme of study was work performance in nutritional control. The data were collected by in-depth interview, direct observation, and document review.

Results: Work performance of nutrition technicians was still sub-optimal so that some of the nutrition recovery program target were not achieved. This problem arose due to various causes, including (1) limited number, low skill, low discipline, and low motivation of the nutrition technicians; (2) lack of monitoring and supervision by health center doctor and municipality health office administrator; (3) limited infrastructure and facilities.

Conclusion: Work performance of nutrition technicians is still sub-optimal due to limited number and low motivation, lack of monitoring and supervision by health center doctor and municipality health office.
\end{abstract}

Keywords: performance, nutrition technicians, nutrition control

\section{Correspondence:}

Gayatri Tungga Dewi. Masters Program in Public Health, Universitas Sumatera Utara, Medan, North Sumatera. Email: gayegayatritunggadewi@gmail.com. Mobile: 08116332270. 